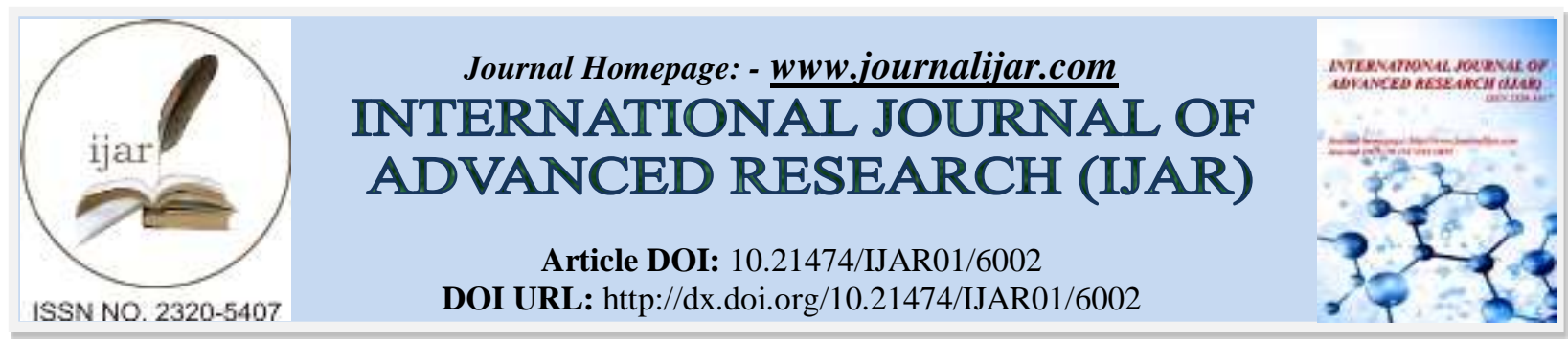

RESEARCH ARTICLE

\title{
THE EFFECT OF LEADER MEMBER EXCHANGE (LMX), TRUST, AND JOB SATISFACTION ON ORGANIZATIONAL CITIZENSHIP BEHAVIOR (OCB) OF THE STATE JUNIOR HIGH SCHOOL TEACHERS IN SURAKARTA.
}

\author{
Heldy Ramadhan Putra $P^{1}$, Suparno Eko Widodo ${ }^{2}$ and Neti Karnati ${ }^{3}$.
}

\section{Manuscript Info}

Manuscript History

Received: 08 October 2017

Final Accepted: 10 November 2017

Published: December 2017

Key words:-

Leader Member Exchange (LMX),

Trust, Job Satisfaction, and

Organizational Citizenship Behavior

(OCB).

\begin{abstract}
The purpose of this research is to study the influence of Leader Member Exchange (LMX), trust, and job satisfaction toward the Organizational Citizenship Behavior (OCB) of teachers in the city of Surakarta. This research uses quantitative approach with survey methods. The sample of this research is 300 Civil Servant (PNS) teachers of SMPN in Surakarta which is appointed randomly from twenty seven (27) SMPN.

The results of this study indicate that: (1) Leader Member Exchange (LMX) has a positive direct effect on Organizational Citizenship Behavior (OCB), (2) trust has a positive direct effect on Organizational Citizenship Behavior (OCB), (3) job satisfaction has a positive direct effect on Organizational Citizenship Behavior (OCB), (4) Leader Member Exchange (LMX) has a positive direct effect on job satisfaction, (5) trust has a positive direct effect on job satisfaction, and (6) Leader Member Exchange (LMX) has a positive direct effect on trust. The conclusion of this research is that Organizational Citizenship Behavior (OCB) is influenced by Leader Member Exchange (LMX), trust, and job satisfaction.
\end{abstract}

Copy Right, IJAR, 2017,. All rights reserved.

\section{Introduction:-}

Education can be viewed as something that can reliably prepare human beings to face the changes that occur in society. Education is not something static, instead it is dynamic; so it always demands a continuous improvement. Education plays a very important role in the process of improving the quality of human resources. Improving the quality of education is a process that is integrated in the process of refining the quality of human resources itself. Recognizing the importance of human resource quality, the government is continuously striving to realize a better quality education through the development and improvement of curriculum and evaluation system, improvement of education facilities, the development and procurement of teaching materials, as well as the training for teachers and other education personnel.

School as an agent of change is expected to realize the changes, values, attitudes, mindset, intellectual behavior, skills and student insight in accordance with the purpose of education itself. Meanwhile, based on the initial interviews between the researcher and the student guardian, complaints are often heard in various circles of societies regarding the low quality of education. Schools are obliged for future quality assurance; therefore, the community's trust in schools as education providers needs to be maintained and improved. 
Junior High School (SMP) is a formal educational institution in charge of implementing the national education program. Schools should be able to translate and capture the essence of macro-education policies and understand their environmental conditions (advantages and disadvantages) and then through the planning process, schools should be able to formulate priority programs in the form of school-level policy to be implemented and evaluated by the schools concerned in accordance with each school's vision and mission.

Teachers are the schools' human resources that have a central role in educational activities in schools and play a role in shaping the character (character building) of the learners who will then be ready to face the reality in the competitive world. Therefore, initiating the role of teachers as contributors is very important and is one of the links that fosters the human resources quality as a substantial matter to be reviewed considering the great expectations of the community towards the educational institutions. In educational management context, teachers are part of the human resource that holds a central role in determining the output of education. This central role is related to the task of teachers as educators in charge of transferring knowledge to the learners, so the role offers a great influence in the learners' way of thinking, behaviour, and manner. Teachers also play a role in internally and externally dynamising the school organization; this significant role is mainly related to the existence of teachers as one of the factors in determining quality education.

The success of a school is determined by individual teachers, since the individual teacher's activity will affect the other teachers. The behavioral demands of today's organization lie not only in performing the role within the organization (in role), but also in the boldness acts beyond the organizational roles (extra role). This behavior leads teachers to take positive actions that benefit the school organization. This behavior (extra-role) is commonly known as Organizational Citizenship Behavior (OCB).

A good school can be seen from the OCB that belongs to the school community. OCB is an in-depth individual contribution beyond the demands of the workplace roles. The OCB involves several behaviors, including the behavior of helping others, becoming a volunteer for extra tasks, and helping the organization to achieve its goals efficiently and effectively.

The statement is in accordance with the opinions of Newstorm and Davis; that is, Organizational citizenship behavior as an employee who are organizational citizens engage in posItive social acts designed to help others, such as volunteering their efforts on special projects, sharing their time and resources, and proactively coopertaing with others. They also are expected to use their talents and energies fully to help the organization achieve its goals of efficiency and effectiveness.

OCB of the employees in the organizations is reflected in the positive social involvement which is designed to help others. The employees are also expected to fully utilize their talents and energies in helping the organization to achieve its goals efficiently and effectively.

Based on the researcher's preliminary appraisal to several schools (15 Junior High Schools) in Surakarta and based on the researcher's experience as a junior high school teacher in Surakarta, a counter phenomenon of OCB indicator can be derived; among others: (1) the limited number of teachers who are willing to engage in the off-the-job discussions to provide an alternative problem solving concerning the teachers' difficulties in the implementation of the teaching and learning process, both in the mastery of subject matter, methods, strategies, classroom management, as well as in the handling of troubled children in the classroom during study time, (2) the lack of teachers who want to foster other teachers both cognate and non-cognate teachers, so the capability of teachers is not evenly distributed, especially in the mastery of technological tools to achieve expertise in the educational information along with the visual aids, especially for mathematics subject (3) some teachers have poor attitudes in the class, for example, having assigned certain tasks to the learners, a teacher handles other activities elsewhere, instead of monitoring the students' progress, (4) the teachers refuse to fully transmit the learning model to their colleagues because they do not want their skills to be imitated by the others, and (5) the teachers are not willing to perform activities apart from their main duties and functions as teachers, such as the lack of teachers who want to work out on the extracurricular activities, conduct imtaq activities, perform environmental deeds including join in activities outside working hours.

This is reinforced by the researcher's interview results with 10 principals of State Junior High School in the city of Surakarta which identified the limitations of OCB in teachers; among others, (1) the limited number of teachers who 
want to assist the principal in the planning of quality learning because the teachers consider that the task of planning is solely the Headmaster task, (2) there are still some teachers who are not punctual, (3) in regards to the learning process, there are teachers who do not prepare the learning tools, such as the RPP, (4) in enforcing the discipline and enhancing the students' character, some teachers only concern with their own students, assuming that the other students are not their responsibility since these teachers do not teach them (5) there are very few teachers who willingly follow the coaching on extracurricular activities, and (6) there are still teachers who do not pay attention to the school progress.

The concern above shows the lack of extra awareness regarding the role in improving the quality of education through continuous quality learning process, the lack of innovation in developing the schools in the face of problems and challenges that arise as well as the limited willingness in doing more for the best interests of the school and educational progress. All of these phenomena serve as the evidence of low OCB in teachers.

In reality, to be able to have strong OCB supporting factors within the school are required, for OCB could not automatically increase without the interaction with other factors. With reference to the various literature, many factors affect the Organizational Citizenship Behavior. Some of these are Leader Member Exchange (LMX), Trust, Job Satisfaction, Emotional Intelligence, Organizational Culture, Managerial Effectiveness, Organizational Commitment, and Leadership. Out of these factors, the ones that could potentially increase OCB are Leader Member Exchange (LMX), Trust, and Job Satisfaction.

Based on the above explanation, it is imperative that a research on the influence of LMX, trust, and job satisfaction towards the OCB of teachers in state SMP of Surakarta is conducted.

\section{Research Methodology:-}

This research uses quantitative approach through survey method. Gay, Mills, and Airasian (2011: 184) gives an overview of survey research as follows:

Survey research involves collecting data to test hypotheses or to answer quetions about people's opinions on some topic or issue. A Survey is an instrument to collect data that describe one or more characteristics of a spesific population.

Survey method is a research method that involves only data collection to test the hypotheses or to answer questions about people's opinions on some topics or issues. In other words survey research is a data collection tool explaining one or more specific population characteristics.

The survey method involves data collection to test the hypotheses or to answer questions about people's opinions on some topics or issues. Survey is an instrument for data collection explaining one or more characteristics of specific population.

The population in this research is all educators/teachers in state junior high school in Surakarta who teach at the state junior high school, reaching the number of 1,500 people, while the affordable population is all Civil Servants (PNS) who teach at the State Junior High School with the total number of 1,200 person.

Samples were taken using simple random sampling technique based on sampling technique formula from Slovin, that is:

Explanation:

$$
n=\frac{N}{N \cdot d^{2}+1}
$$

$n \quad$ : number of samples

$N \quad$ : population

$d^{2} \quad$ :error tolerance limit which is set to 5\% means it has an accuracy of 95\%

Using the above formula, the result is as follows:

$n=\frac{1200}{1200 \cdot(0,05)^{2}+1}=\frac{1200}{4}=300$ 
Data collection is carried out using an instrument in the form of a questionnaire to measure the four variables of research, namely LMX $\left(X_{1}\right)$, trust $\left(X_{2}\right)$, job satisfaction $\left(X_{3}\right)$, and OCB $(Y)$ variables. The indicators of each variable are conveyed in the form of questions presented in the questionnaires which are prepared based on the theoretical basis of the source of reference.

The influence between variables in this study was analyzed by using path analysis technique (path analysis). This analytical technique is believed to have the usefulness in assessing the influence between variables based on the theoretical formulas and it is not used to bring down the cause and effect theory. The consequence of using this technique is the necessity of employing causal thinking which is a prerequisite in path analysis.

\section{Research Result and Discussion:-}

The path calculation is divided into 3 (three) sub-structures namely: (1) The effect of $\operatorname{LMX}\left(X_{1}\right)$, trust $\left(X_{2}\right)$, and job satisfaction $\left(X_{3}\right)$, on OCB $(Y)$. (2) The effect of LMX $\left(X_{1}\right)$, trust $\left(X_{2}\right)$ on job satisfaction $\left(X_{3}\right)$. (3) The effect of LMX $\left(X_{1}\right)$ on trust $\left(X_{2}\right)$.

The calculation of path coefficient substructure 1 (one)

The result of substructure 1 (one) calculation can be seen in Table 1.1 below:

Tabel 1.1:- Path Coefficient Substructure 1 (one)

Coefficients $^{\mathrm{a}}$

\begin{tabular}{|c|c|c|c|c|c|c|}
\hline \multicolumn{2}{|c|}{ Model } & \multicolumn{2}{|c|}{ Unstandardized Coefficients } & \multirow{2}{*}{$\begin{array}{c}\begin{array}{c}\text { Standardized } \\
\text { Coefficients }\end{array} \\
\text { Beta }\end{array}$} & \multirow[t]{2}{*}{$\mathrm{T}$} & \multirow[t]{2}{*}{ Sig. } \\
\hline & & B & Std. Error & & & \\
\hline \multirow[t]{4}{*}{1} & (Constant) & 40.091 & 7.263 & & 5.520 & .000 \\
\hline & $X_{1}$ & .167 & .081 & .139 & 2.066 & .040 \\
\hline & $X_{2}$ & .184 & .092 & .138 & 2.013 & .045 \\
\hline & $X_{3}$ & .276 & .076 & .235 & 3.653 & .000 \\
\hline
\end{tabular}

a. Dependent Variable: OCB $(Y)$

Based on the output in Table 4:14 above, the standardized regression coefficient (Beta) for LMX $\left(X_{1}\right)$ on OCB $(Y)$ $\rho_{y 1}$ with a value of 0.139 is obtained, trust on $\operatorname{OCB}(Y) \rho_{y 2}$ with a value of 0.138 , and job satisfaction on OCB $(Y) \rho_{y 2}$ with a value of 0.235 . Thus, the path coefficient formed on the model of substructure equation 1 (one) is:

$$
\begin{gathered}
Y=\rho_{y 1} X_{1}+\rho_{y 2} X_{2}+\rho_{y 3} X_{3} \\
Y=0,139 X_{1}+0,138 X_{2}+0,235 X_{3}
\end{gathered}
$$

The calculation of path coefficient substructure 2 (two)

The results of substructure 2 (two) calculations can be seen in Table 1.2 below:

\begin{tabular}{|c|c|c|c|c|c|c|}
\hline \multicolumn{7}{|c|}{ Coefficients $^{\mathrm{a}}$} \\
\hline \multirow{2}{*}{\multicolumn{2}{|c|}{ Model }} & \multicolumn{2}{|c|}{ Unstandardized Coefficients } & \multirow{2}{*}{$\begin{array}{c}\begin{array}{c}\text { Standardized } \\
\text { Coefficients }\end{array} \\
\text { Beta }\end{array}$} & \multirow[t]{2}{*}{$\mathrm{T}$} & \multirow[t]{2}{*}{ Sig. } \\
\hline & & $\mathrm{B}$ & Std. Error & & & \\
\hline \multirow[t]{3}{*}{1} & (Constant) & 30.511 & 5.282 & & 5.777 & .000 \\
\hline & $X_{1}$ & .293 & .060 & .285 & 4.898 & .000 \\
\hline & $X_{2}$ & .414 & .066 & .365 & 6.267 & .000 \\
\hline
\end{tabular}

Tabel 1.2:- Path Coefficient Substructure 2 (two).

a. Dependent Variable: Job Satisfaction $\left(X_{3}\right)$

Based on the output in Table 4:15 above, the standardized regression coefficient (Beta) for LMX $\left(X_{1}\right)$ on job satisfaction $\rho_{31}$ with a value of 0.285 is obtained and trust on job satisfaction $\rho_{32}$ with a value of 0.365 . Thus the path coefficient formed on the model of substructure equation 2 (two) namely:

$$
\begin{gathered}
X_{3}=\rho_{31} X_{1}+\rho_{32} X_{2} \\
X_{3}=0,285 X_{1}+0,365 X_{2}
\end{gathered}
$$

The calculation of path coefficient substructure 3 (three)

The result of substructure 3 (three) calculation can be seen in Table 4.16 below: 
Tabel 1. 3:- Path Coefficient Substructure 3 (three)

\begin{tabular}{|c|c|c|c|c|c|c|}
\hline \multicolumn{7}{|c|}{$\begin{array}{cc}\text { Coefficients }^{\mathbf{a}} \\
\end{array}$} \\
\hline \multirow{2}{*}{\multicolumn{2}{|c|}{ Model }} & \multicolumn{2}{|c|}{ Unstandardized Coefficients } & \multirow{2}{*}{$\begin{array}{c}\begin{array}{c}\text { Standardized } \\
\text { Coefficients }\end{array} \\
\text { Beta }\end{array}$} & \multirow[t]{2}{*}{$\mathrm{T}$} & \multirow[t]{2}{*}{ Sig. } \\
\hline & & B & Std. Error & & & \\
\hline \multirow[t]{2}{*}{1} & (Constant) & 39.281 & 4.040 & & 9.724 & .000 \\
\hline & $X_{1}$ & .527 & .043 & .583 & 12.382 & .000 \\
\hline
\end{tabular}

Based on the output in Table 4:16 above, the standardized regression coefficient (Beta) for LMX $\left(X_{1}\right)$ on trust $\left(X_{2}\right)$ $\rho_{21}$ with a value of 0.583 is obtained. Thus, the path coefficient formed on the model of substructure equation 3 (three) namely:

$$
\begin{gathered}
X_{2}=\rho_{21} X_{1} \\
X_{2}=0,583 X_{1}
\end{gathered}
$$

Next, the final model of the path diagram as shown in Figure 4.5 is as follows:

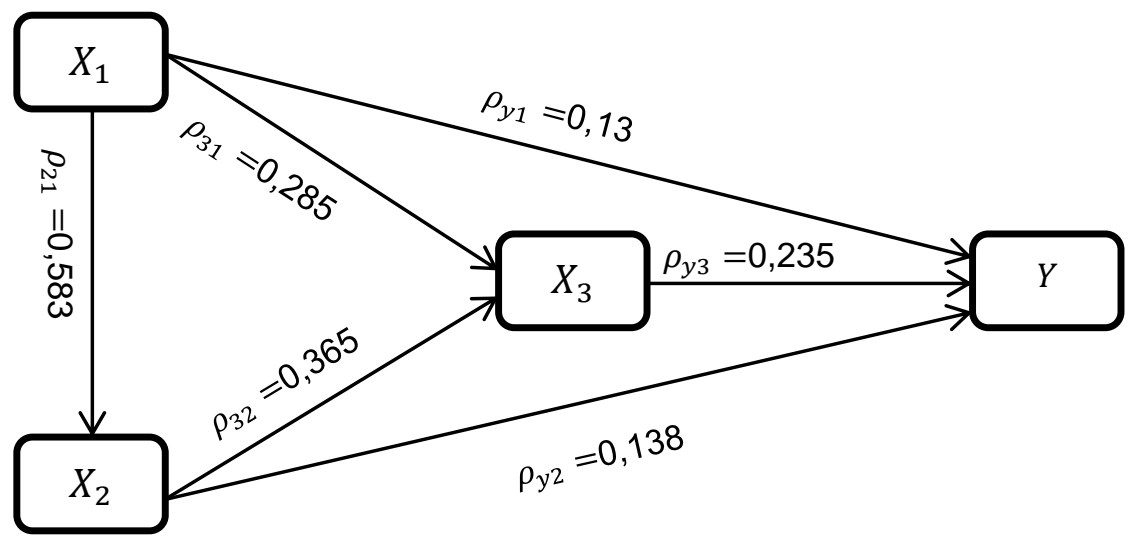

Gambar 1.1:- End Model of Line Chart

Figure 1.1 shows the final model of the LMX path diagram $\left(X_{1}\right)$, trust $\left(X_{2}\right)$, and job satisfaction $\left(X_{3}\right)$ on OCB $(Y)$. Based on the structural model assessment, the hypothesis testing can be explained as follows.

The First Hypothesis:- there is a positive direct effect of $\operatorname{LMX}\left(X_{I}\right)$ on $\operatorname{OCB}(Y)$.

To examine that there is a positive direct effect of LMX $\left(X_{1}\right)$ on OCB $(Y)$, the hypothesis tested statistically is as follows:

$$
\begin{aligned}
& H_{0}: \beta_{y 1} \leq 0 \\
& H_{1}: \beta_{y 1}>0
\end{aligned}
$$

From the calculation of path coefficient, a positive direct effect path of LMX on OCB $\rho_{y l}$ with the value of 0.139 is obtained. The value of $t_{\text {count }}=2.066$, while the value of $t_{\text {table }}$ at the level of significance is $\alpha(0.05)=1.968$. Because $t_{\text {count }}>t_{\text {table }}$, then $H_{0}$ is rejected and $H_{1}$ is accepted. Thus, it can be concluded that LMX has a positive direct effect on OCB.

The Second Hypothesis:- there is a positive direct effect of trust $\left(X_{2}\right)$ on $\operatorname{OCB}(Y)$.

To examine that there is a positive direct effect of trust $\left(X_{2}\right)$ on OCB $(Y)$, the hypothesis tested statistically is as follows:

$$
\begin{aligned}
& H_{0}: \beta_{y 2} \leq 0 \\
& H_{1}: \beta_{y 2}>0
\end{aligned}
$$

From the calculation of path coefficient, a positive direct effect path of trust on OCB $\rho_{y 2}$ with the value of 0.138 is obtained. The value of $t_{\text {count }}=2.013$, while the value of $t_{\text {table }}$ at the level of significance is $\alpha(0.05)=1.968$. Because $t_{\text {count }}>t_{\text {table }}$, then $H_{0}$ is rejected and $H_{1}$ is accepted. Thus it can be concluded that trust has a positive direct effect on OCB. 
The Third Hypothesis:- there is a positive direct effect of job satisfaction $\left(X_{3}\right)$ on OCB $(Y)$.

To examine that there is a positive direct effect of job satisfaction $\left(X_{3}\right)$ on OCB $(Y)$, the hypothesis tested statistically is as follows:

$$
\begin{aligned}
& \mathrm{H}_{0}: \beta_{\mathrm{y} 3} \leq 0 \\
& \mathrm{H}_{1}: \beta_{\mathrm{y} 3}>0
\end{aligned}
$$

From the calculation of path coefficient, a positive direct effect path of trust on OCB $\rho_{y 3}$ with the value of 0.235 is obtained. The value of $t_{\text {count }}=3.653$, while the value of $t_{\text {table }}$ at the level of significance is $\alpha(0.05)=1.968$. Because $t_{\text {count }}>t_{\text {table }}$, then $H_{0}$ is rejected and $H_{1}$ is accepted. Thus, it can be concluded that job satisfaction has a positive direct effect on OCB.

The Fourth Hypothesis:- there is a direct positive effect of LMX $\left(X_{1}\right)$ on job satisfaction $\left(X_{3}\right)$

To examine that there is a positive direct effect of LMX $\left(X_{1}\right)$ on job satisfaction $\left(X_{3}\right)$, the hypothesis tested statistically is as follows.

$$
\begin{aligned}
& \mathrm{H}_{0}: \beta_{31} \leq 0 \\
& \mathrm{H}_{1}: \beta_{31}>0
\end{aligned}
$$

From the calculation of path coefficient, a positive direct effect path of $\operatorname{LMX}\left(X_{1}\right)$ on job satisfaction $\rho_{31}$ with the value of 0.285 is obtained. The value of $t_{\text {count }}=4.898$, while the value of $t_{\text {table }}$ at the level of significance is $\alpha(0.05)=$ 1.968. Because $t_{\text {count }}>t_{\text {table }}$, then $H_{0}$ is rejected and $H_{l}$ is accepted. Thus, it can be concluded that LMX has a positive direct effect on job satisfaction.

The fifth Hypothesis:- there is a positive direct effect of trust $\left(X_{2}\right)$ on job satisfaction $\left(X_{3}\right)$

To examine that there is a positive direct effect of trust $\left(X_{2}\right)$ on job satisfaction $\left(X_{3}\right)$, the hypothesis tested statistically is as follows:

$$
\begin{aligned}
& \mathrm{H}_{0}: \beta_{32} \leq 0 \\
& \mathrm{H}_{1}: \beta_{32}>0
\end{aligned}
$$

From the calculation of path coefficient, a positive direct effect path of trust $\left(X_{2}\right)$ on job satisfaction $\rho_{32}$ with the value of 0,365 is obtained. The value of $t_{\text {count }}=6.267$, while the value of $t_{\text {table }}$ at the level of significance is $\alpha(0.05)=$ 1.968. Because $t_{\text {count }}>t_{\text {table }}$, then $H_{0}$ is rejected and $H_{1}$ is accepted. Thus, it can be concluded that trust has a positive direct effect on job satisfaction.

The Sixth Hypothesis:- there is a positive direct effect of LMX $\left(X_{1}\right)$ on trust $\left(X_{2}\right)$

To examine that there is a positive direct effect of LMX $\left(X_{1}\right)$ on trust $\left(X_{2}\right)$, the hypothesis tested statistically is as follows:

$$
\begin{aligned}
& \mathrm{H}_{0}: \beta_{21} \leq 0 \\
& \mathrm{H}_{1}: \beta_{21}>0
\end{aligned}
$$

From the calculation of path coefficient, a positive direct effect path of LMX $\left(X_{1}\right)$ on trust $\rho_{21}$ with the value of 0.583 is obtained. The value of $t_{\text {count }}=12.382$, while the value of $t_{\text {table }}$ at the level of significance is $\alpha(0.05)=1.968$. Because $t_{\text {count }}>t_{\text {table }}$, then $H_{0}$ is rejected and $H_{l}$ is accepted. Thus, it can be concluded that LMX has a positive direct effect on trust.

From the hypothesis results as described above, a discussion that links the theories and the relevant research is provided as follows.

The effect of LMX on OCB:-

Based on the hypothesis results, it was concluded that LMX has a positive direct effect on OCB. The results of this study are in line with the research conducted by Rashidah Mohamad Ibrahim, Aziz bin Amin, and Munir Salleh, who stated that,

The study has proven and supported the social exchange theory that LMX has been able to exert significant influence on OCB level among local government employees in East Coast Malaysia arising from a quality exchange being experienced in the dyadic relationship. Hence, in this study based on local government setting found that quality LMX relationship being established drives and motivates the 
subordinates to reciprocate and perform various forms of OCB for organizational effectiveness at relatively low cost.

This study proves and supports the LMX theory as a significant influence on the level of OCB among local government employees in the East Coast of Malaysia arising from quality relationships. Therefore, this study concludes that the quality of a good LMX relationship will motivate subordinates to counter and perform various forms of OCB for organizational effectiveness at a relatively low cost.

LMX is the quality of mutual relationships between superiors and subordinates. Some indicators that reflect a good reciprocal relationship are; firstly, a leader must be able to recognize the potential and position of his subordinates; secondly, there is a sense and desire to support each other; thirdly, there are leaders who understand the workplace issues. The effectiveness of an effective working relationship will result in the feed back or moral duty of the subordinates that will instigate extra-role behavior or OCB from the subordinates.

\section{The effect of trust on OCB:-}

From the results of the second hypothesis, it can be concluded that there is a positive direct effect of trust on OCB. The results of this study are similar to those proposed by Jason A. Colquitt, Jeffery A. Lepine, and Michael J. Wesson which stated that,

Trust has a moderate positif effect on performance. Employees who are willings to be vulnarable to authorities tend to have higher levels of task performance. They are also more likely to engage in citizenship behavior and less likely to engage in counterproductive behavior.

Trust has a positive effect on overall performance. Teachers who are willing to put themselves in charge are more likely to have a higher level of performance appraisal. They are also more likely to engage in OCB and are less likely to engage in counterproductive behavior.

Trust among school members is critical to the efficiency and effectiveness of school organizations. On the basis of trust, it is expected that the principal as a leader can show effective leadership in the organization, so that the organization can run properly. Mutual trust is needed in school organizations. Over mutual trust, school organization members are likely to work optimally which will then lead to an increase in OCB.

\section{The effect of job satisfaction on OCB:-}

From the results of the third hypothesis, it can be concluded that job satisfaction has a positive direct effect on OCB. The results of this study are consistent with the research conducted by Gonzaga M. F. Deonisio et al, who concluded that,

This study result proves that job satisfaction significantly affect on OCB both directly and indirectly through organizational commitment of employees. This means that job satisfaction is directly able to increase the OCB and organizational commitment of employees, as well as high organizational commitment can improve OCB of employee.

The results of this study prove that job satisfaction has a significant effect on OCB either directly or indirectly through the organization commitment of employees. This means that job satisfaction is capable of increasing the $\mathrm{OCB}$ and organization commitment of employees directly. A prominent organizational commitment can increase the OCB of the employees.

Job satisfaction is one of the most important factors in obtaining an optimal work result. A person with a high level of job satisfaction has a positive attitude towards his job, and someone who is not satisfied with his work will have a negative attitude towards the job. Job satisfaction reflects one's feelings toward one's work. This can be seen through the positive attitude of employees regarding the job and everything confronted in the work environment. Therefore, work satisfaction will guarantee that the teachers will work to the best of his ability in completing the task and will tend to do more for the sake of the progress of the school. 


\section{The effect of LMX on Job Satisfaction:-}

From the results of the fourth hypothesis, it can be concluded that LMX has a positive direct effect on job satisfaction. The results of this study are consistent with the opinion of some experts among whom is Greenberg that explained,

Leader member exchange (LMX) suggesting that leaders from diffrent relations with various subordinates and that the nature of such dyadic exchanges can exert strong effects on subordinates performance and satisfaction.

LMX shows that principals who have different relationships with teachers can have a strong influence on teacher performance and satisfaction.

LMX is an approach that emphasizes the importance of varied relationships between superiors and their subordinates or between principals and teachers. A quality relationship between the principals and teachers will trigger mutual trust, mutual reverence, and mutual respect. The existence of a quality reciprocal relationship with the principals will allow teachers to have a high level of job satisfaction and will be motivated to work further towards the school organization progress.

\section{The effect of trust on job satisfaction:-}

From the results of the fourth hypothesis, it can be concluded that trust has a positive direct effect on job satisfaction. The results of this study are similar to the opinions of Robbins and Coulter who claim that, "Research has shown that trust in leadership is related to positive job outcomes, including job performance, organizational citizenship behavior, job satisfaction, and organizational commitment." Trust in leadership is significantly related to positive work outcomes, including job performance, OCB, job satisfaction, and organizational commitment.

The mutual trust between principals and teachers is needed in school organizations. Through mutual trust, school organization members are likely to work optimally. Trust among school members is critical to the efficiency and effectiveness of school organizations. On the basis of trust, it is expected that the principal as a leader can demonstrate effective leadership for school organizations.

\section{The effect of LMX on trust:-}

From the results of the fourth hypothesis valuation, it can be concluded that LMX has a positive direct effect on trust. The results of this study are in line with the opinions of John R. Schermerhorn, Hunt and Osbon, which stated that "some relationships are high quality (high LMX) partnerships, characterized by mutual trust, respect, and loyalty."

The quality of good relationships between principals and teachers will result in mutual trust between principals and teachers on a reciprocal basis so that teachers will feel at ease in working; thus, will perform their best as a kind of dedication to the school.

\section{Conclusion:-}

Based on the results of the analysis and discussion that have been described in the previous chapter, the conclusion of this study is as follows: (1) Leader Member Exchange (LMX) has a positive direct effect on Organizational Citizenship Behavior (OCB). That is, an increase in LMX caused an increase in OCB of state Junior High School teachers in Surakarta, (2) trust has a positive direct effect on Organizational Citizenship Behavior (OCB). That is, the increase in confidence resulted in an increase in the OCB of state Junior High School teachers in Surakarta, (3) job satisfaction has a positive direct effect on Organizational Citizenship Behavior (OCB). That is, the increase in job satisfaction resulted in an increase in the OCB of state Junior High School teachers in Surakarta, (4) LMX has a positive direct effect on job satisfaction. That is, the precision of LMX causes an increase in job satisfaction of state Junior High School teachers in Surakarta, (5) trust has a positive direct effect on job satisfaction. That is, the increase in trust resulted in an increase in job satisfaction of state Junior High School teachers in Surakarta, (6) LMX has a positive direct effect on trust. That is, the conducive LMX precision resulted in an increase of trust in state Junior High School teachers in Surakarta.

\section{Implication:-}

The results of this study led to several related implications. Some of the implications will be explained as follows: (1) Efforts to realize teachers' OCB through LMX improvement. LMX is a theory of leadership which is related to 
the improvement of relationships between leaders and subordinates in achieving organizational goals as the main goal. The interaction process between leaders and subordinates should continue to evolve over time. Efforts made to improve LMX are by improving the two-way relationship between the principal and the teacher through; increasing the interaction between school principals and teachers, assistance provided by the principals for the teachers, duties and responsibilities being carried out to the utmost by the principals as examples for teachers. (2) Efforts to realize OCB through trust. To realize OCB of teachers can be done through increased trust. Efforts that can be done is to instil an honest and trusting attitude among teachers and all communities that exist in school. The principal should be able to become a figure who understands the needs of the teachers; namely, teachers want to be involved in decision-making related to school and teachers want to be given an appreciation for the tasks they have carried out. (3) Efforts to realize OCB through job satisfaction. The increase in teachers work satisfaction is expected to run in a straight line with the increase in OCB of teachers because with a sense of satisfaction in work, teachers become more satisfied in carrying out their duties so as not to feel burdened with their duties as educators; moreover, teachers are also expected to demonstrate their work performance that goes beyond the job description.

\section{Bibliography:-}

1. Gay, L.R., Geoffrey E Mills, dan Peter Airasian, Educational Research Competencies for Analysis and Applications), Tenth Edition, USA: Pearson Education, Inc., 2011.

2. Gonzaga M. F. Deonisio, Sudiro Achmad, Surachman, dan Noermijati, Organizational Commitment and Job Satisfaction as a Mediator the Effect of Leadership Style on Organizational Citizenship Behavior of Employees, Vol 9 (31), 2015

3. Jason A. Colquitt, Jeffrey A. Lepine dan Michael J. Wesson, Organizational Behavior Improving Performance and Commitment in Workplace, New York: McGraw-Hill, 2011.

4. Jerald Greenberg, Behavior in Organizations, 10 ${ }^{\text {th }}$ Edition, London: Pearson Education, 2011

5. Jhon W. Newstorm and Keith Davis, Organizational Citizenship Behavior, Human Behavior at Work, $11^{\text {th }}$ Edition, Boston: McGraw-Hill, 2002.

6. John R. Schermerhorn, Hunt and Osbon, Organizational Behaviour, New York: John Wiley \& Sons. Inc., 2005.

7. Rashidah Mohamad Ibrahim, Aziz bin Amin, dan Munir Salleh, The Role of Leader-Member Exchange in Elevating Local Government Employees'Organizational Citizenship Behavior:An Empirical Evidence from East Coast Malaysia, International Journal of Business and Social Science, 2014, Vol. 5, No. 6. 2014.

8. Stephen P. Robbins and Mary Coulter, Management, $11^{\text {th }}$ Edition, New Jersey: Pearson Education Limited, 2013. 